\title{
Bate-papo com a professora Geni Rosa Duarte, do coletivo Paulo Freire de São Paulo: sobre memórias e vivências de uma educação política e libertadora
}

Filipe Rafael Gracioli ${ }^{1}$

http://orcid.org/0000-0002-3240-9594

Andreia Osti ${ }^{2}$

https://orcid.org/0000-0002-7605-2347

${ }^{1}$ IPHAN - Instituto do Patrimônio Histórico e Artístico Nacional/CLC - Centro Lucio Costa, Rio de Janeiro, Rio de Janeiro - Brasil. E-mail: filipe-rg@ @otmail.com

${ }^{2}$ Universidade Estadual Paulista, UNESP - Rio Claro, São Paulo - Brasil. E-mail:

andreia.osti@unesp.br

Estimado(a) leitor(a)!

A revista Educação: teoria e prática, publicação de fluxo contínuo do programa de pós-graduação em Educação da UNESP - Campus Rio Claro, em comemoração ao centenário de Paulo Freire, educador, pensador e homem do povo brasileiro apresenta, neste outubro de 2021, como parte dos seus trabalhos de editoração anual o dossiê "Paulo Freire faz 100 anos", seção especial que conta com a publicação de produções textuais e audiovisuais com a temática envolvendo a vida, a obra e o pensamento deste grande mestre, para que sempre o relembremos como marco fundamental na busca pela construção de uma educação democrática e libertadora, especialmente nestes tempos sombrios para a política, a arte, a cultura e a educação em nosso país.

Sabemos que as dificuldades e impasses no cenário político nacional têm sido muitos e graves, mas o desejo por uma educação com base na liberdade dos sujeitos nos conduz ao resgate de termos como força, coragem, esperança e vontade de potência para fazermos frente a esses momentos que nos assolam e que, somados a uma crise sanitária de dimensões planetárias, se fazem gritos de resistência na defesa por uma sociedade mais digna para todos. 
Nesse sentido, a revista Educação: teoria e prática, no compromisso social e coletivo de atenção às normas de exigências sanitárias que nos impelem ao distanciamento social propôs-se à criação de um espaço de articulação entre ideias e pensadores de modo a, ainda que pela geografia distanciados, podermos estar intelectualmente e sensivelmente aproximados a partir do diálogo com as temáticas da educação, nas suas muitas dimensões e possibilidades. Como todos já sabemos, mais que nunca as videoconferências e os encontros virtuais têm dado hoje a tônica de nossos trabalhos e a proposta da revista, nesse sentido, é a de também nos articularmos com as possibilidades que a tecnologia nos proporciona nessa jornada rumo à difusão de ideias e de sentidos outros.

E assim apresentamos, no documento audiovisual que segue, um bate-papo com a professora e membro do coletivo Paulo Freire de São Paulo, Geni Rosa Duarte ${ }^{\mathrm{i}}$, cujo trabalho e dedicação intelectual no âmbito da educação com um sentido libertador foi se fazendo sua proposta de ser-no-mundo. A professora Geni Rosa Duarte, atualmente aposentada pela Universidade Estadual do Oeste do Paraná (UNIOESTE), onde atua como professora associada, é graduada em Ciências Sociais e História, mestre e também doutora em História e trabalhou ao longo de sua trajetória profissional e intelectual com temas como ensino de história, cultura popular, linguagens e produtores culturais nos campos da música popular, da música caipira, da literatura, fotografia, cinema e do rádio, além da história oral. ${ }^{1}$ Foi professora da rede básica de ensino do município de São Paulo e também professora em nível superior, passando pela Educação de Jovens e Adultos nos anos 1990, quando as discussões em torno desta modalidade de educação popular ganhava novos ares e um novo fôlego com atores como Luísa Erundina e Paulo Freire injetando-lhe potência.

Por ter participado diretamente deste movimento de renovação conceitual e prática da escola pública brasileira, que contou com o suporte legal de textos como o da então recém instituída Constituição Federal de 1988 e o da Lei no . 9394/1996, a Lei de Diretrizes e Bases da Educação Nacional (LDB), a professora Geni Duarte traz em seu repertório de memórias contribuições que são mais que simples relatos ou registros cotidianos desinteressados: são verdadeiros documentos de memória de um tempo de movimentos políticos que entendiam a reestruturação da educação nacional no Brasil como uma questão de dignidade e de acolhimento social. A partir de sua prática docente e da vivência de temas de pesquisas no campo dos estudos sociais, as experiências da professora Geni Duarte com a educação de base nas propostas de Paulo Freire têm para nós um sentido de práxis que muito nos ajudarão a refletir sobre a nossa própria atuação profissional, como docentes, alunos, gestores, pais e demais participantes da vida escolar. 
No bate-papo que alegremente apresentamos, a professora Geni Duarte, participante ativa do Coletivo Paulo Freire de São Pauloii, organização nascida da insatisfação de intelectuais com a proposta de retirada do nome de Paulo Freire como patrono da educação brasileira, cujos trabalhos têm se desdobrado sobre as suas ideias na divulgação de práticas, relatos, manifestos, da memória e de afetos deste pensador e sujeito político brasileiro, a professora nos convida a um diálogo com as ideias de Paulo Freire experimentadas por ela tanto em suas atividades profissionais, quanto em sua proposta política de atuação no mundo, resgatando momentos, situações, comentários de experiências pessoais e conceituais sobre as ideias do pensador e sua pertinência mais que atual, necessária para a educação no Brasil.

Esperamos que você aprecie o material que carinhosamente divulgamos na intenção de promover um movimento de registro de falas e de ideias de sujeitos ativamente envolvidos com a produção intelectual e política de Paulo Freire e de crítica ao que temos pensado e feito como educação em nosso país. Agradecemos imensamente à professora Geni pelo apoio na contribuição com nossos trabalhos na composição deste dossiê que, esperamos, possa nos auxiliar a rememorar falas, atos e sensações necessários à nossa proposta de educação libertadora no dia a dia da escola, da universidade, da família, da rua e, também, prestar-se como homenagem àquele que foi e é, certamente, um dos mais importantes pensadores do Brasil e do mundo dos últimos tempos.

Viva Paulo Freire!

\footnotetext{
' Acesso ao Currículo Lattes: http://lattes.cnpq.br/1066779488649379 e e-mail para contato: geni.rosaduarte@gmail.com

ii Coletivo Paulo Freire: https://sites.google.com/unesp.br/coletivopaulofreire/in\%C3\%ADcio
} 